\title{
Diseminasi Model Belajar Siswa Aktif Dengan Pendekatan Alqur'an, Sains, Dan Karakter Untuk Meningkatkan Sikap Dan Hasil Belajar Siswa Untuk Guru Di Mi Tamrinussibyan
}

\author{
Dwi Hesty Kristyaningrum ${ }^{1}$, Ujang Khiyarusholeh ${ }^{2}$, Aqib Ardiansyah ${ }^{3}$, Winarto ${ }^{4}$ \\ 1,2,3,4 Universitas Peradaban,Jalan Raya Pagojengan KM 3 Brebes, Telp 0289432032 \\ 1,2,3,4 Program Studi Pendidikan Guru Sekolah Dasar Universtias Peradaban \\ Email:1 dwihestikristyaningrum@gmail.com, ${ }^{2}$ ujang606bk@ gmail.com, \\ ${ }^{3}$ ardi_atsauroh@yahoo.co.id, ${ }^{4}$ wiwin16@gmail.com
}

\begin{abstract}
Abstrak
Artikel ini membahas deskripsi pelaksanaan Program Kemitraan Masyarakat Stimulus (PKMS) Tahun 2019 yang didanai oleh Kementerian Riset Teknologi dan Pendidikan Tinggi (RISTEKDIKTI). Kegiatan ini dilatar belakangani belum diterapkannya model pembelajaran yang menggunakan alqur'an sebagai sumber belajar IPA. Permasalahan pritoritas mitra yaitu guru belum mengetahui konseptual model belajar siswa aktif dengan pendekatan ALSAK. Selain itu, guru belum mengetahui perencanaan, pelaksanaan, dan penyusunan sumber serta instrument evaluasi. Solusi yang ditawarkan yaitu memberikan pengetahuan tentang pembelajaran model ALSAK untuk guru MI di Tamrinussibyan. Metode pelaksanaan kegiatan PKMS ini adalah ceramah, diskusi, workshop, peerteaching, dan penugasan. Kegiatan ini dilaksanakan selama tiga bulan yaitu Juni-Agustus 2019. Luaran kegiatan ini yaitu peningkatan pengetahuan guru MI dalam menyusun rencana pelaksanaan pembelajaran sebesar 80\%, melaksanakan pembelajaran sebesar 70\% dan menyusun sumber belajar serta instrument evaluasi sebesar 70\%. Selain itu, luaran kegiatan PKMS ini berupa publikasi media massa berupa koran suara merdeka, video pelaksanaan, dan artikel.
\end{abstract}

Kata Kunci: Diseminasi, Model ALSAK, PKMS, Guru MI.

\section{PENDAHULUAN}

Pendidikan karakter diajurkan oleh pemerintah untuk dilaksanakan pada semua jenjang pendidikan. Pembentukan karakter melalui pembelajaran diharapkan menjadi pondasi kuat untuk berhasil dalam ranah pengetahuan, sikap, dan keterampilan sehingga dapat memecahkan masalah rendahnya literasi siswa Indonesia, dan degradasi moral. Pemerintah menyusun rencana jangka panjang tentang pendidikan karakter. Dalam buku rencana strategis nasional tahun 2010-2025 dituliskan bahwa pembangunan karakter yang merupakan upaya perwujudan amanat Pancasila dan Pembukaan UUD 1945 dilatarbelakangi oleh realita permasalahan kebangsaan yang berkembang saat ini, seperti: disorientasi dan belum dihayatinya nilai-nilai Pancasila; keterbatasan perangkat kebijakan terpadu dalam 
mewujudkan nilai-nilai Pancasila; bergesernya nilai etika dalam kehidupan berbangsa dan bernegara; memudarnya kesadaran terhadap nilai-nilai budaya bangsa; ancaman disintegrasi bangsa; dan melemahnya kemandirian bangsa.

Saat ini, pembelajaran yang dilakukan guru cenderung berorientasi menstransfer pengetahuan kepada peserta didik belum menanamkan nilai-nilai kebaikan (noble values). Banyak kasus kriminal yang melibatkan pelajar seperti pencurian, seks bebas, narkoba, dan tawuran yang menyebabkan kematian. Tindakan kriminal yang dilakukan pelajar mengindikasi pembelajaran yang dilakukan oleh guru belum menanamkan nilai-nilai kebaikan, didukung pula peran masyarakat yang kurang peduli. Salah satu solusi yang dapat dilakukan oleh guru yaitu penanaman karakter melalui mata pelajaran. Nilai-nilai yang direncanakan dalam kegiatan pembelajaran akan muncul pada aktivitas peserta didik. Pendidikan karakter sudah seharusnya diajarkan kepada siwa, tidak terkecuali pada jenjang pendidikan sekolah dasar. Pendidikan karakter yang diintegrasikan dalam pembelajaran, tentunya memerlukan suatu model yang tepat agar tujuan dapat tercapai. Model belajar merupakan pengelolaan kegiatan belajar yang dilakukan oleh guru dan siswa untuk mencapai tujuan. Model belajar disesuaikan dengan dengan kakteristik dan kebutuhan siswa. Pendekatan diperlukan untuk melengkapi model belajar[1].

Menurut Rutherford and Ahlgren pendidikan sains dapat menolong peserta didik untuk mengembangkan pemahaman dan kebiasaan berpikir yang diperlukan sebagai manusia yang memiliki tenggang rasa yang dapat berpikir untuk dirinya sendiri dan bangsanya [2]. Character based approach perlu diterapkan dalam setiap mata kuliah untuk mengembangkan sikap saling keterkaitan antara sains dan moral [3]. Hasil penelitian Mahmudah pengajaran yang mengkombinasikan antara ilmu agama (spiritual) dan ilmu pengetahuan (sains) [4]. Pengajaran menggunakan pendidikan spiritual di kelas diharapkan menghasilkan peserta didik yang berkarakter. Karakter yang tertanam dalam diri peserta didik integritas (kejujuran), energik (semangat), wisdom (bijaksana), inspiration (banyak ide) dan spirit (kuat). Penelitan yang dilakukan Khusniati tentang imlementasi pendidikan karakter melalui pembelajar IPA pendidikan karakter dalam proses pembelajaran dilaksanakan mulai dari tahap perencanaan, pelaksanaan, hingga evaluasi. Pelaksanaan pembelajaran IPA membutuhkan pendekatan belajar untuk mendukung pencapaian kecerdasan spiritual dan keterampilan generik sains. Pendekatan merupakan titik tolak atau sudut pandang terhadap proses pembelajaran/cara yang dapat didekati untuk keberhasilan tujuan pembelajaran [5]. Pendekatan ALSAK (alqur'an, sains dan karakter) merupakan suatu gagasan kegiatan belajar dengan cara mendekatkan mahasiswa kepada qur'an sebagai sumber belajar tentang konten IPA, cara mempelajari IPA, dan nilai-nilai religius). Pendekatan ALSAK diyakini mendukung implementasi pendidikan karakter karena didalamnya memuat pendekatan indoktrinasi, pendekatan klasifikasi nilai 
dengan cara penalaran dan keterampilan, pendekatan keteladanan, dan pendekatan pembiasaan yang sudah digunakan oleh praktisi pendidikan karakter. Pendekatan indoktrinasi dengan cara memberikan hukuman, hadiah, dan pengendalian fisik. Pendekatan klasifikasi nilai dengan cara penalaran dan keterampilan. Pendekatan keteladanan dilakukan dengan cara mengajarkan untuk disiplin, tanggung jawab, empati, dan lainnya. Pendekatan pembiasaaan dengan cara berperilaku seperti berdoa, membaca kitab suci, berpuasa, dan aktivitas lainnya yang membiasakan keteladanan [6]. Ayat-ayat Al-Qur'an yang memerintahkan manusia mencari ilmu atau menjadi ilmuwan begitu banyak. Al-Qur'an menggunakan berbagai istilah yang berkaitan dengan hal ini. Misalnya, mengajak melihat, memperhatikan, dan mengamati kejadian-kejadian (Fathir: 27; al-Hajj: 5; Luqman: 20; al- Ghasyiyah: 17-20; Yunus: 101; alAnbiya': 30), membaca (al-'Alaq: 1-5) supaya mengetahui suatu kejadian (al-An'am: 97; Yunus: 5), supaya mendapat jalan (al-Nahl: 15), menjadi yang berpikir atau yang menalar berbagai fenomena (al-Nahl: 11; Yunus: 101; al-Ra'd: 4; al-Baqarah: 164) [7].

PKMS merupakan salah satu solusi untuk memecahkan masalah mitra program ini melatih para guru untuk melaksanakan Pembelajaran dengan Model ALSAK merupakan hal yang penting sebagai upaya untuk menanamkan karakter anak yang berlandaskan nilai-nilai keislaman tanpa mengurangi pengetahuan umum, sehingga para guru di sekolahan tersebut memiliki pemahaman tentang nilai-nilai karakter pada anak. Oleh karena itu, perlu diberikan perhatian khusus dengan memberikan pelatihan pendidikan ALSAK untuk guru.

Berdasarkan analisis permasalahan yang dihadapi oleh mitra, solusi yang dipilih berdasarkan prioritas permasalahan adalah pelatihan melaksankan ALSAK untuk guru di Sekolah Dasar Islam ini sebagai upaya untuk meningkatkan karakter keislaman anak. Program PKMS model ALSAK diharapkan memberikan kegunaan bagi guru berupa:

1. Membekali dan meningkatkan pemahaman guru tentang konsep pelaksanaan pembelajaran model ALSAK.

2. Membekali dan meningkatkan pemahaman guru tentang langkah-langkah pelaksanaan pembelajaran model ALSAK.

3. Membekali dan meningkatkan pemahaman guru dalam merencanakan, melaksanakan, dan mengevaluasi pelaksanaan pembelajaran model ALSAK.

4. Membekali dan meningkatkan pemahaman guru dalam memilih/menyusun media pembelajaran model ALSAK.

5. Membekali dan meningkatkan pemahaman guru dalam menyusun dan memilih intrumen dan teknik penilaian pelaksanaan pembelajaran model ALSAK. 


\section{Gambaran IPTEK PKMS}

IPTEK yang diberikan kepada mitra adalah konseptual model ALSAK dan impelemtasi model tersebut di sekolah dasar. Gambaran IPTEK yang diberikan sebagai berikut:

1. Pengetahuan konseptual tentang Model Belajar Siswa Aktif dengan Pendekatan ALSAK

Model belajar siswa aktif pendekatan ALSAK merupakan ide tentang gambaran kegiatan belajar yang dilakukan guru dan siswa dengan mengutamakan keaktifan siswa sepenuhnya untuk mencapai kompetensi pengetahuan, keterampilan dan sikap sesuai dengan capaian pembelajaran dalam K13. Konsep model belajar siswa aktif yang dikembangkan disajikan pada gambar 1.

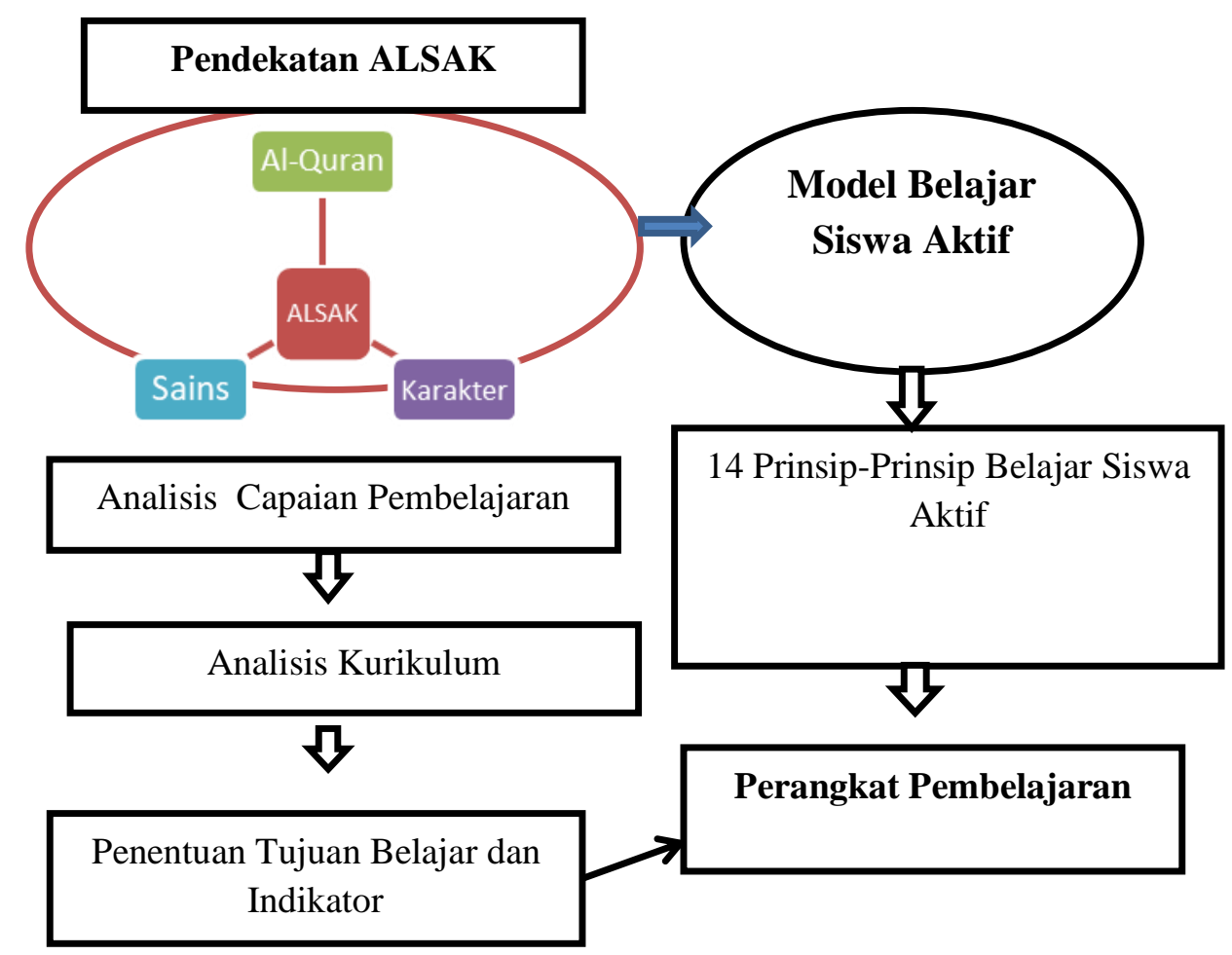

Gambar 1 Konseptual Model Belajar Siswa Aktif ALSAK

2. Penyusunan perangkat pembelajaran model ini terdiri dari tiga tahap. Penjelasan masing-masing tahapan sebagai berikut.

Implementasi model belajar siswa aktif dengan pendekatan ALSAK merupakan penjelasan dan contoh bagaimana melaksanakan model ini di SD. Hal-hal yang perlu diperhatikan yaitu usia siswa, dan perkembangan fisik serta mentalnya. Langkah-langkah melaksanakan model ini sebagai berikut: 
a. Analisis Peta Konsep Capaian Pembelajaran.

Analisis materi dan tema dengan menemukan keterkaitan qur'an dengan sains, sosial dan karakter untuk menghasilkan suatu peta konsep. Konsep-konsep keterpaduan dijadikan dasar untuk menentukkan tema. Pemilihan tema haruslah yang menarik minat siswa, kontekstual, dan menumbuhkan rasa ingin tahu. Contoh hasil langkah 1 disajikan pada gambar 2 .

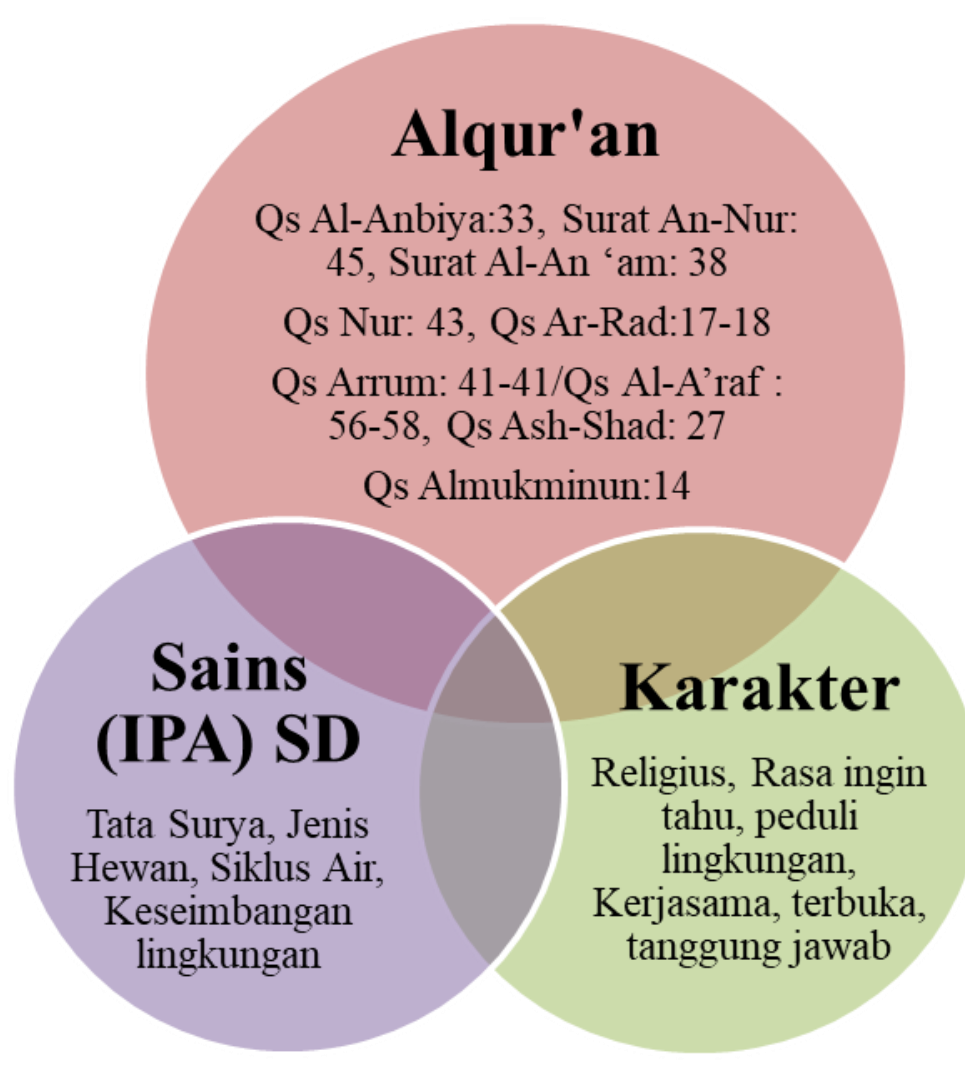

Gambar 2 Contoh Hasil Analisis Langkah 1.

b. Analisis Kurikulum

Analisis kurikulum berpedoman pada hasil analisis capaian pembelajaran. Analisis kurikulum memperhatikan kompetensi/bidang yang dikembangkan kompetensi sikap, pengetahuan, dan keterampilan.

c. Menyusun perangkat pembelajaran

Perangkat pembelajaran yang disusun berupa silabus, Rencana Pelaksanaan Pembelajaran (RPP), dan Lembar Kerja Siswa (LKS). Penyusunan perangkat pembelajaran memperhatikan prinsip-prinsip belajar siswa aktif. Siswa mendominasi kegiatan belajar sepenuhnya, merupakan karakteristik dari model ini.Pendekatan Alqur'an digunakan dalam menyusun pembelajaran yang dituangkan dalam silabus dan RPP serta LKS. 


\section{METODE}

Metode pelaksanaan kegiatan PKMS terdiri dari empat tahap. Tahapan -tahapan dijelaskan sebagai berikut.

A. Persiapan Pelatihan Pembelajaran model ALSAK

Kegiatan ini bertujuan untuk mempersiapkan fasilitas, peserta, tempat, dan materi pelatihan sehingga pelaksanaan pelatihan lebih terencana dan terstruktur. Kegiatan persiapan terdiri dari (1) sosialisasi program PKMS kepada guru-guru Sekolah Dasar Islam Ta'alumul Huda Bumiayu. (2) Survei lokasi/tempat pelatihan bertujuan untuk memberikan kemudahan, dan kenyamanan kepada peserta selama pelatihan. Tempat dilaksanakannya pelatihan di SD Islam Ta'alumul Huda Bumiayu.(3) Penyusunan materi pelatihan melibatkan para ahli pendidikan di universitas peradaban. Hal ini dilakukan sebagai upaya mempersiapkan materi pelatihan yang lengkap dan menyeluruh.(4) Menyusun jadwal pelaksanaan pelatihan.

B. Pelaksanaan Pelatihan model ALSAK

Kegiatan pelaksanaan terdiri dari empat kegiatan. Penjelasan masing-masing kegiatan sebagai berikut.

1. Penyampaian materi konsep pembelajaran model ALSAK

Kegiatan ini dilaksanakan dengan metode ceramah dan diskusi. Kegiatan diawal pelatihan berupa penyampaian materi tentang langkah-langkah perencanaan, pelaksanaan, dan penilaian pembelajaran model ALSAK. Setelah penyampaian materi, guru diberikan kesempatan untuk memberikan pertanyaan. Pemecahan masalah ketidaktahuan konsep pembelajaran model ALSAK kegiatan ini dapat diselesaikan. Metode ceramah ini memberikan pemahaman guru tentang konsep pembelajaran model ALSAK. Tingkat pemahaman guru tentang pembelajaran model ALSAK dapat diukur dari Rencana Pelaksanaan Pembelajaran (RPP)/ tes pemahaman.Target penguasaan materi oleh peserta pelatihan sebesar $75 \%$ dari jumlah peserta secara keseluruhan menguasai konsep pembelajaran model ALSAK.

2. Pelatihan menyusun langkah-langkah pembelajaran model ALSAK yang dituangkan dalam Rencana Pelaksanaan Pembelajaran (RPP)

Kegiatan ini dilaksanakan menggunakan metode ceramah, diskusi, praktek, dan penugasan. Kegiatan di awal diberikan penjelasan materi tentang kegiatan menganalsisis materi pelajaran yang akan di integrasikan dengan model ALSAK, pemilihan tema, dan pemilihan model serta metode pembelajaran. Setelah penyampaian materi, peserta pelatihan diberikan tugas untuk membuat RPP. Selama penyusunan RPP, instruktur mendampingi peserta pelatihan. Penugasan terstruktur untuk menyusun RPP diberikan kepada peserta pelatihan sebagai pengembangan 
kemampuan menyusun RPP. Metode kegiatan ini bertujuan guru mampu merencanakan kegiatan pembelajaran model ALSAK yang dituangkan dalam penyusunan RPP dengan baik. Target pencapaian kemampuan peserta pelatihan dalam menyusun RPP dengan baik sebesar 75\% dari jumlah peserta secara keseluruhan. Kualitas RPP yang telah disusun peserta pelatihan dapat diukur menggunakan lembar penilaian dokumen.

3. Pelatihan Menyusun Bahan Ajar dan Pemilihan media Pembelajaran

Kegiatan ini dilaksanakan menggunakan metode ceramah, diskusi, praktek, dan penugasan. Kegiatan di awal diberikan penjelasan materi tentang jenis-jenis media pembelajaran, karakteristik media dan manfaatnya, dan pemilihan media. Dan penyusunan bahan ajar. Setelah penyampaian materi, peserta pelatihan diberikan tugas untuk membuat bahan ajar.Selama penyusunan bahan ajar, instruktur mendampingi peserta pelatihan. Penugasan terstruktur untuk menyusun bahan ajar diberikan kepada peserta pelatihan sebagai pengembangan kemampuan menyusun bahan ajar. Metode kegiatan ini bertujuan agar guru mampu menggunakan media dan menyusun bahan ajar yang digunakan dalam pembelajaran model ALSAK pada anak dengan tepat. Target pencapaian kemampuan peserta pelatihan dalam menyusun bahan ajar/pemilihan mediadengan baik sebesar $75 \%$ dari jumlah peserta secara keseluruhan. Kualitas media/bahan ajat yang digunakan peserta pelatihan dapat diukur menggunakan lembar penilaian bahan ajar/media.

4. Pelatihan penyusunan instrumen penilaian

Kegiatan ini dilakukan dengan metode ceramah, diskusi, praktek, dan penugasan. Kegiatan pertama dijelaskan tentang teknik dan jenis penilaian pembelajaran model ALSAK pada anak, pedoman penskoran, kompetensi yang diukur, dan penyusunan kisi-kisi soal. Setelah penyampaian materi, peserta pelatihan diberikan tugas untuk membuat instrumen penilaian berdasarkan RPP yang telah disusun. Selama penyusunan instrumen penilaian, instruktur mendampingi peserta pelatihan. Metode ini bertujuan agar guru mampu menyusun instrumen penilaian pembelajaran model ALSAK pada anak yang dituangkan dalam penyusunan kisi-kisi, butir, dan pedoman penskoran dengan baik. Target pencapaian kemampuan peserta dalam menyusun instrumen penilaian dengan baik sebesar $75 \%$ dari jumlah peserta secara keseluruhan. Penugasan terstruktur untuk menyusun instrumen diberikan kepada peserta pelatihan sebagai pengembangan kemampuan menyusun instrumen penilaian dengan berbagai macam kompetensi inti, dan karakteristik materi. Kualitas instrumen penilaian yang telah disusun peserta pelatihan dapat diukur menggunakan lembar penilaian. 
5. Praktek pembelajaran model ALSAK pada anak

Kegiatan ini dilakukan dengan metode praktek, dan tanya jawab. Semua peserta secara berurutan menjadi guru model dan yang lainnya sebagai siswa. Peserta pelatihan diberikan waktu mengajar selama 40 menit. Materi pelajaran yang digunakan dalam kegiatan praktek mengajar, haruslah berbeda masing-masing peserta. Hal ini dilakukan dengan tujuan, peserta pelatihan mendapatkan pengetahuan dan pengalaman yang bervariasi. Setelah kegiatan praktek mengajar selesai, dilanjutkan kegiatan refleksi dan evaluasi praktek mengajar. Semua peserta diberikan kesempatan untuk memberikan penilaian, saran, dan evaluasi terhadap praktek mengajar satu sama lain serta konfirmasi dari instruktur. Kegiatan praktek mengajar menjadi tolak ukur tingkat penguasaan peserta terhadap materi yang disampaikan. RPP dan bahan ajar serta instrumen penilaian yang telah disusun, digunakan sebagai pedoman melaksanakan praktek pembelajaran. Metode praktek yang digunakan dalam kegiatan ini bertujuan agat guru SD Islam ta'alumul Huda Bumiayu mampu melaksanakan pembelajaran model ALSAK pada anak dengan baik dari aspek perencanaan, pelaksanaan, dan penilaian serta evaluasi. Target kemampuan peserta dalam praktek mengajar sebesar $75 \%$ dapat melaksanakan pembelajaran model ALSAK pada anak dengan baik. Kualitas pelaksanan praktek mengajar oleh peserta dapat diukur menggunakan lembar penilaian antar teman dan performa mengajar.

Evaluasi program dan keberlanjutan

Evaluasi program dilakukan terhadap penguasaan materi pelatihan, kepuasaan peserta terhadap pelatihan mengajar dan dampak pelatihan. Evaluasi penguasaan materi dilakukan pada akhir mata acara kegiatan. Evaluasi program setelah seluruh kegiatan pelatihan selesai dilakukan. Evaluasi kepuasaan dengan memberikan angket penilaian program. Evaluasi dampak program dilakukan ketika peserta pelatihan melaksanakan aktivitas pembelajaran di sekolah masing-masing.

\section{HASIL DAN PEMBAHASAN}

\section{Rencana Pembelajaran}

Rancangan program pembelajaran adalah kegiatan PKMS yang sudah disusun guru selama pelaksanaan program. Hasil evaluasi rencana pembelajaran disajikan sebagai berikut. 


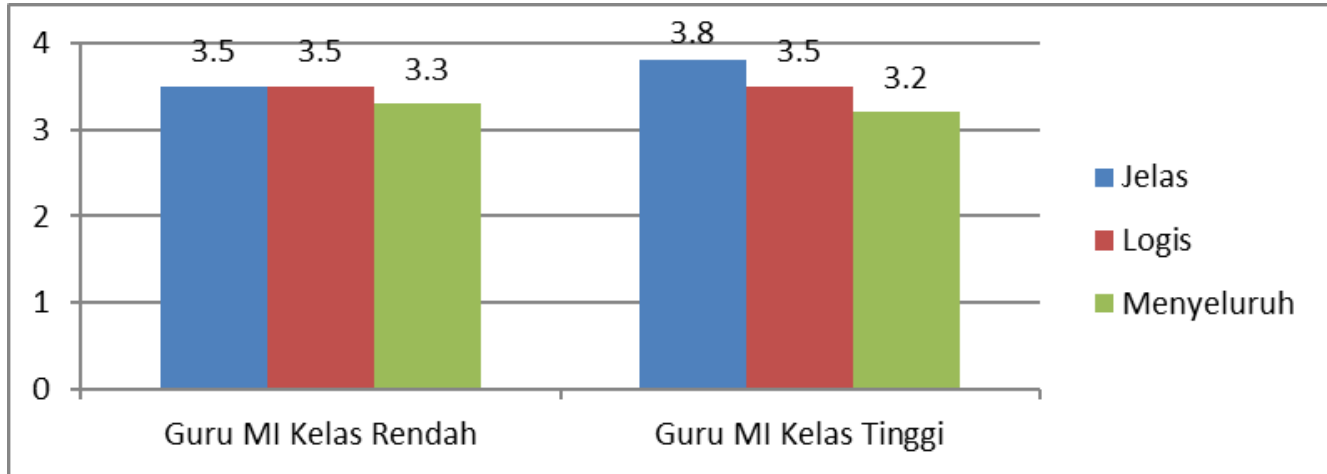

Gambar 3 Evaluasi Rencana Pembelajaran PKMS

Hasil evaluasi rencana pembelajaran program PKMS diperoleh informasi rata-rata mendapatkan kategori baik. Perserta PKMS masing-masing sekolah sudah mempersiapkan rancangan pembelajaran, media, bentuk penilaian dan evaluasi yang jelas, logis, dan menyeluruh. Persentase pencapaian keterlakasanan rencana pembelajaran $\geq 90 \%$ kategori baik.

\section{Kualitas Perangkat Pembelajaran}

Kuliatas perangkat pembelajaran merupakan evaluasi terhadap keterampilan guru danmerancang perangkat pembelajaran yang terbaik. Kualitas perangkat pembelajaran dilakukan oleh ahli. Hasil evaluasi perangkat pembelajaran sebagai berikut.

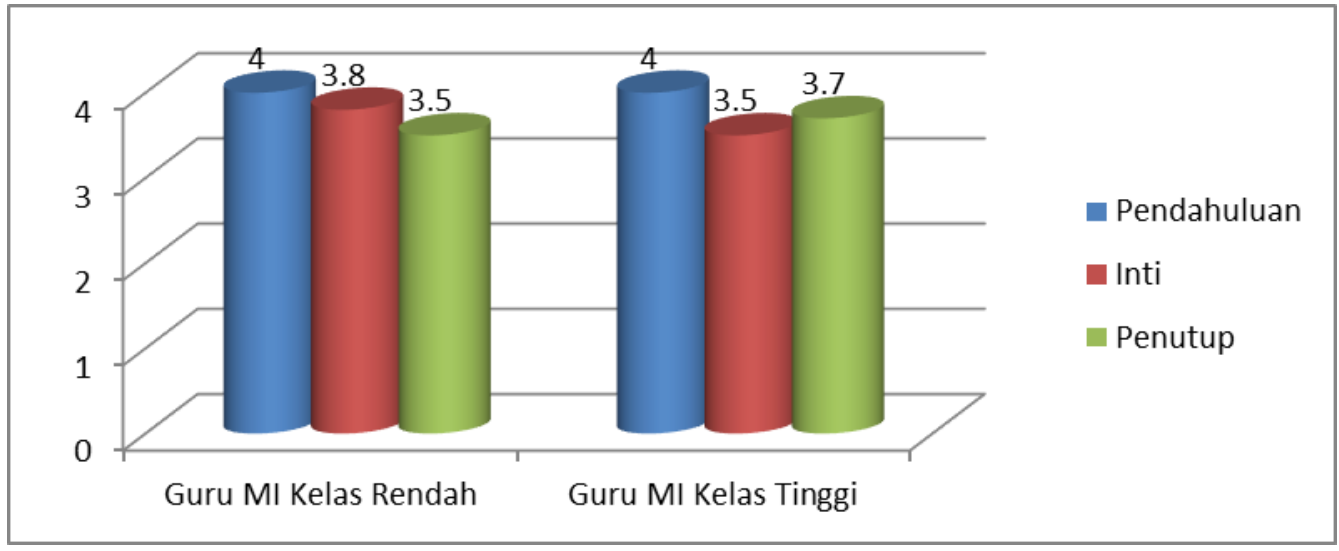

Gambar 4 Evaluasi Kualitas Perangkat Pembelajaran

Hasil evaluasi perangkat pembelajaran yang disusun guru dalam kategori baik. Penilaian terhadap perangkat mencakup rancangan kegiatan pendahuluan, inti, dan penutup. Persentase pencapaian kualitas perangkat pembelajaran $\geq 90 \%$ kategori baik. 


\section{Kualitas Pelaksanaan Pembelajaran}

Kuliatas pembelajaran merupakan evaluasi terhadap keterampilan guru dan dosen melaksanakan pembelajaran yang terbaik. Kualitas pembelajaran dilakukan oleh ahli dengan malakukan pengamatan langsung. Hasil evaluasi kualitas pembelajaran sebagai berikut.

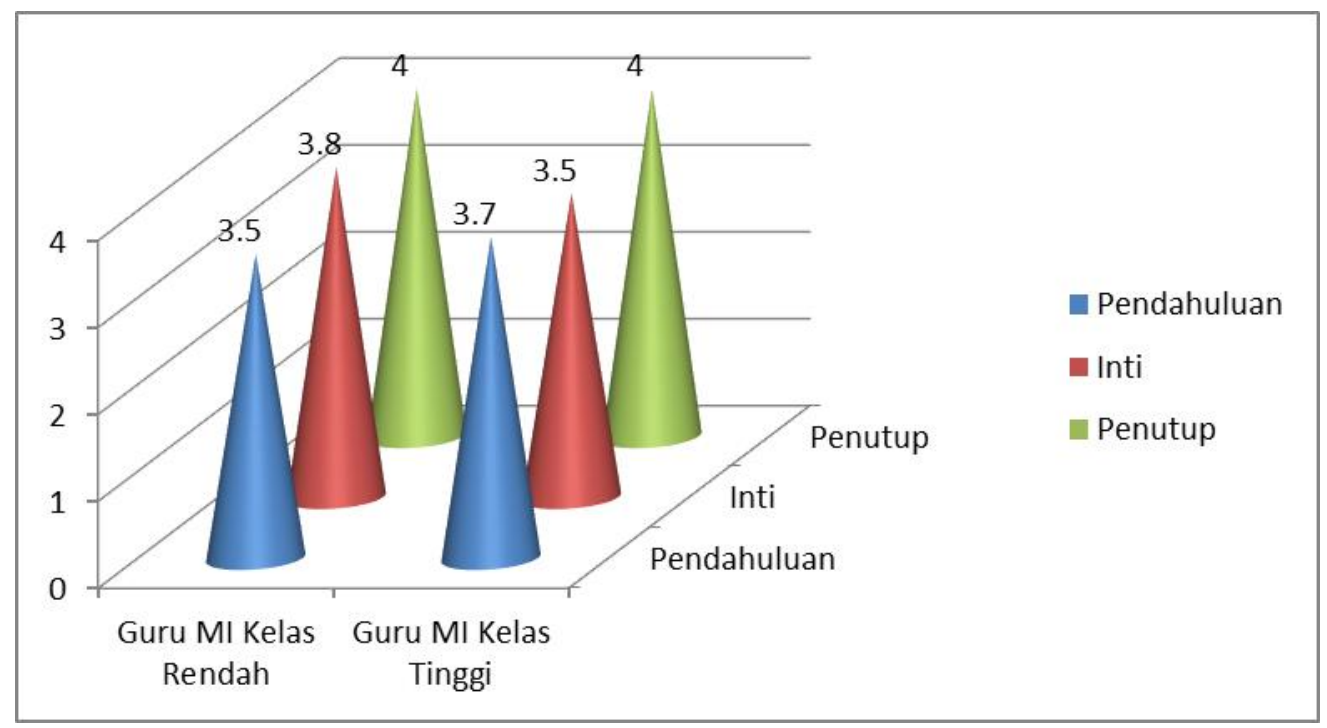

Gambar 5. Evaluasi Kualitas Perangkat Pembelajaran

Hasil evaluasi pelaksanaan pembelajaran yang dilakukan guru dalam kategori baik. Penilaian terhadap pelaksanaan kegiatan pendahuluan, inti, dan penutup. Persentase pencapaian kualitas perangkat pembelajaran $\geq 90 \%$ kategori baik.

\section{SIMPULAN}

Luaran kegiatan ini yaitu peningkatan pengetahuan guru MI dalam menyusun rencana pelaksanaan pembelajaran sebsesar $80 \%$, melaksanakan pembelajaran sebesar $70 \%$ dan menyusun sumber belajar serta instrument evaluasi sebesar 70\%. Selain itu, luaran kegiatan PKMS ini berupa publikasi media massa berupa koran suara merdeka, video pelaksanaan, dan artikel.

\section{SARAN}

Kegiatan PKMS memberikan banyak manfaat kepada mitra tentang pengetahuan model pembelajaran inovatif. Mitra mengharapkan adanya kerjasama yang berkelanjutan dengan memberikan pengetahuan yang berbeda sesuai dengan permasalahan dan kebutuhan 
mitra. Oleh karena itu, skema PKMS bisa ditambahkan besaran dana yang didanai dan jika hasil monitoring evaluasi terhadap kegiatan PKMS tahun pertama dinilai baik dan berhasil maka perlu ada skema PKMS lanjutan tidak hanya satu tahun.

\section{UCAPAN TERIMA KASIH}

Program Kemitraan Masyarakat Stimulus (PKMS) tahun 2019 melibatkan pihakpihak yang mendukung kegiatan ini. Ucapan terima kasih diucapkan kepada Kementerian Riset Teknologi dan Pendidikan Tinggi yang telah memberikan pendanaan kegiatan ini tahun anggaran 2019. Selain itu, kami mengucapkan kepada kepala sekolah dan guru MI Tamrinussibyan yang telah bersedia menjadi mitra kegiatan PKMS ini.

\section{DAFTAR PUSTAKA}

[1] Zuhdi, Darmiyati, (2011) Pendidikan Karakter. Yogyakarta

[2] Liliasari, et al.2011, Scientific Concept and Generic Science Skill Relationship in The 21st Century Science Education Makalah, Pada seminar International I SPs UPI : Bandung

[3] Winarni, F. (2006). Reorientasi Pendidikan Nilai Dalam Menyiapkan Kepemimpinan Masa Depan. Jurnal Cakrawala Pendidikan: No 1, 130-171

[4] Mahmudah, Laely. 2016. Spiritual Teaching dalam Pembelajaran IPA di Madrasah. Jurnal Penelitian Pendidikan Islam, 11 (2): 448

[5] Arends, I. Richard. (2007). Learning to Teach Seven Edition (Alih bahasa: Drs. Helly Prajitno, M.A dan Dra. Sri Mulyantini). Yogyakarta: Pustaka Pelajar

[6] Sudaryanti. (2010). Pentingnya Pendidikan Karakter Anak Usia Dini dalam Mewujudkan Warga Negara yang Baik. Makalah Pengabdian Masyarakat Fakultas Ilmu Pendidikan Universitas Negeri Yogyakarta. Diakses dari http:staf.uny.ac.id pada tanggal 8 Agustus 2015.

[7] Djudin, Tomo. (2010). Menyisipkan Nilai-Nilai Agama Dalam Pembelajaran Sains: Suatu Alternatif Memagari Keimanan Siswa. Jurnal Fakultas Pendidikan danIlmu Pendidikan Universitas Tanjungpura. 